\author{
Krzysztof Hwaszcz, Dorota Klimek-Jankowska \\ Institute of English Studies, University of Wrocław
}

\title{
The Role of Semantic Transparency in the Processing of Compound Words in Polish: Evidence from a Masked Priming Experiment
}

\begin{abstract}
The main goal of the reported study is to test the cross-linguistic validity of the existing psycholinguistic models of morphological processing by contributing the results of a masked priming lexical decision experiment on the processing of Polish semantically transparent and opaque compounds. All these models are concerned with the question of whether morphologically complex words are decomposed during online processing or whether they are stored as chunks in the mental lexicon. We contribute new data from Polish showing that reaction times to target words semantically related to the heads of transparent compounds were significantly faster than to target words semantically related to the heads of opaque compounds in Polish. This may be interpreted as evidence in favour of the view that semantically transparent compound words are decomposed and we access the lemmas of their constituent elements whereas semantically opaque compounds are not decomposed and there is no access to their constituent lemmas.
\end{abstract}

\section{Keywords}

morphology, language processing, Polish compound words, complex words, semantic transparency, lexical decision, masked priming

\section{Streszczenie}

Przedmiotem artykułu jest weryfikacja istniejących modeli psycholingwistycznych opisujących przetwarzanie wyrazów morfologicznie złożonych w mentalnym leksykonie. Wszystkie te modele koncentrują się na pytaniu, czy wyrazy morfologicznie złożone są dekomponowane na bieżąco podczas przetwarzania języka, czy są one przechowywane jako nierozłączna całość. Aby odpowiedzieć na to pytanie, zaplanowaliśmy eksperyment z wykorzystaniem torowania semantycznego i decyzji leksykalnej, dla dwóch typów polskich wyrazów złożonych: (i) transparentnych znaczeniowo (przewidywalnych, np. bajkopisarz) i (ii) nietransparentnych znaczeniowo (nieprzewidywalnych, np. żóttodziób), gdzie jednostkami prymującymi były wyrazy semantycznie związane z ośrodkami tych wyrazów złożonych (np. autor i buzia). Otrzymane wyniki zostały skonfrontowane z podobnymi badaniami, które skupiały się na przetwarzaniu wyrazów złożonych w innych językach. Niniejsze badanie dostarcza nowych danych z języka polskiego i demonstruje, że trans- 
parentne wyrazy złożone wywoływały istotnie krótsze czasy reakcji, niż nietransparentne wyrazy złożone. Wyniki te można zinterpretować jako dowód na to, że transparentne wyrazy złożone są dekomponowane i możliwy jest dostęp do lemm ich części składowych, a nietransparentne wyrazy złożone nie są dekomponowane, a lemmy ich komponentów są niedostępne.

\section{Słowa kluczowe}

morfologia, przetwarzanie języka, wyrazy złożone, język polski, transparentność semantyczna, językoznawstwo eksperymentalne

\section{Introduction - setting the scene ${ }^{1}$}

\section{Theoretical approaches to the status of morphological pro- cesses in the linguistic system}

Both in theoretical and in psycholinguistic literature there is a great deal of controversy as to the locus of morphological processes in the linguistic system. As stated in Embick and Noyer (2007), in purely theoretical linguistic studies there exist two competing views on the syntax/morphology interface or, in other words, on the issue of whether the rules which underlie the formation of morphologically complex words are related to the rules which underlie the formation of syntactic structures: the lexicalist view and the constructionist view. According to the lexicalist view, both morphologically complex words and syntactic objects are derived in separate modules of the grammar. Morphologically complex words are derived in the Lexicon and syntactic objects are created in Syntax. Under this view, there is a strict separation of syntax and morphology. There is no relation between the composition of words and syntactic objects. On the other hand, under the constructionist view, both complex words and syntactic objects are derived in Syntax. According to this view, there is a single generative component in which all complex objects (morphological and syntactic) are composed based on the same set of rules.

\section{Psycholinguistic approach to the processing of morphologi- cally complex words}

Independently of this theoretical discussion, in psycholinguistic investigations, studies related to the processing of morphologically complex words generally assume that morphological processes happen in the mental lexicon. In this sense, they are more compatible with the lexicalist view postulated

\footnotetext{
${ }^{1}$ We would like to thank Professor Bożena Rozwadowska and two anonymous reviewers for their insightful and valuable comments on the paper as these comments led us to a considerable improvement of the work. This work was funded by a grant awarded to Krzysztof Hwaszcz by the Faculty of Letters, University of Wrocław (0420/1743/16).
} 
in the theoretical linguistic discussion. In psycholinguistics, much attention has been paid to the question of how different types of morphologically complex words are represented in the mental lexicon and whether users compose words during online production and comprehension. There is a growing body of evidence pointing to the fact that some morphologically complex words are stored as unified wholes and other morphologically complex words are decomposed in the online processing and this depends on a number of factors such as the type of morphological composition (inflection, derivation, compounding), the degree of semantic transparency, frequency, familiarity and the type of language under investigation. For example, Newman et al. (2007) contribute important evidence coming from their ERP (i.e. eventrelated potentials) ${ }^{2}$ experiments showing that regular and irregular past tense verbs are not computed from stems in an analogous manner but rather the former are rule-governed combinations, whereas the latter are lexically memorized chunks. Newman et al. (2007) report a LAN (i.e., left anterior negativity) component (typically interpreted as an electrophysiological response to morphosyntactic agreement violations) for violations in the formation of regular (but not for irregular) past tense verbs. They take this finding to indicate that processing regular forms is compositional, whereas irregular past tense verbal forms are stored as chunks in the mental lexicon. The difference between regular and irregular past tense verbs is that the former are productive and the latter form a closed set of items. The role of productivity of morphological processes was also tested in Bradley (1980), who reports a priming effect for more frequent stems as compared to less frequent stems only in derived words with productive endings -ness and -ment but not for the ones with less productive affixes -ous, -ary. This may suggest that more productive morphologically complex words are composed online during processing whereas less productive morphologically complex words are stored as memorized chunks in the mental lexicon (see Vannest and Boland 1999 for a similar view). Let us extend this reasoning one step further and take into account the fact that there are important cross-linguistic differences in the productivity of some word formation processes. One such example is compounding, which is very productive in German and in English but less productive in Polish (see Szymanek 2014 for a comparison between English and Polish compounding). This makes it reasonable to hypothesize that the same classes of morphologically complex words may be processed differently in different languages depending on the degree of productivity of their formation in a particular language. This motivates cross-linguistic research related to the processing of morphologically complex words and comparing the results of studies conducted in

\footnotetext{
${ }^{2}$ It is a procedure that measures an electrophysiological response of the brain to a specific sensory, cognitive or motor event.
} 
languages in which such words are formed productively and in languages in which there are considerable constraints on the formation of morphologically complex words.

\section{Motivation for the reported research on the processing of compound words in Polish}

In psycholinguistic studies on morphological processing the main attention has been paid to inflection and derivation (see Taft Forster 1975; Manelis, Tharp 1977; Caramazza et al. 1988; Marslen-Wilson et al. 1993; Marslen-Wilson, Tyler 1998; Münte et al. 1999; Devlin et al. 2004; Longtin, Meunier 2005; Lück et al. 2006, among others). These scholars have contributed a substantial amount of evidence pointing to the validity of specific models of morphological processing. Recently, a number of new studies have contributed to this discussion by conducting experiments related to the morphological processing of compound words. Compound words require a slightly different treatment because they consist of two or more independent roots in contrast to adjoining one or more affixes to a single root, as is the case with inflection or derivation (Libben 1998).

A central question is whether all compound words follow the same processing routes, or whether different compounds follow different processing routes, depending on factors, such as semantic transparency, the type of language, the frequency of occurrence. Within this set of factors influencing the processing of compounds, semantic transparency is correlated with productivity in that semantically opaque compounds are much less productive than semantically transparent compounds. The main goal of this paper is to test current approaches to the processing of morphologically complex words in a lexical decision experiment with the use of visually presented Polish compound words differing in the degree of semantic transparency. The models of morphological processing relevant for the presented experimental study are discussed in the subsequent section.

\section{Psycholinguistic models of morphological processing}

Within the set of the existing models of morphological processing, a full-listing model (Butterworth 1983) is one of the most radical ones. According to this model, all complex words are separately stored in the mental lexicon and are connected with one another by associative links. Taft's (2004) full-parsing model holds that morphological decomposition is obligatory for all morphologically complex words and it happens very early (before lexical access). Dualroute models postulate that some forms are stored and accessed as full forms and some forms are decomposed into morphemes. Dual-route models can be 
divided into the Augumented Addressed Morphology Model (AAM) postulated by Caramazza et al. (1988) and the Morphological Race Model (MRM) by Schreuder and Baayen (1995). The AAM assumes that whether we decompose morphologically complex words depends on their familiarity with the restriction that full-form access is the default and faster route for familiar complex words, while constituent decomposition is faster only for considerably less familiar or novel complex words. On the other hand, the MRM assumes that the way compound words are accessed is determined on the basis of such factors as semantic transparency and frequency. The more transparent and frequent the complex word is, the higher the probability that it will be processed via the decomposition route. In other words, any factor that facilitates access to morpheme-based representations ends up decreasing the level of full form activation and prevents whole word access.

\section{The role of semantic transparency in the processing of com- pound words}

Traditional approaches to compound processing are based on the models outlined above and focus on the differences in the processing of compound words depending on their semantic transparency. The first one is the Conjunctive Activation Approach (CAA) due to Libben (1998), which posits that the meanings of transparent components speed compound processing, while the meanings of opaque components bear no influence on the processing. The second one is the Meaning Computation Approach (MCA) due to Ji et al. (2011), which assumes that the activation of semantic representations of components occurs irrespectively of compound transparency, i.e. both opaque and transparent constituents' semantic representations are activated and computed into a combined representation. However, the meanings of opaque components slow down the processing as the computed meaning contradicts the traditional lexicalized meaning and thus has to be rejected to the benefit of the stored meaning. The latter two models will be of particular relevance in our reported study.

\section{Relevant experimental studies on the processing of com- pounds}

The majority of the data on the role of semantic transparency in compound processing come from single language studies (Libben, Jarema 2002). Crosslinguistic evidence that may shed some more light on the issue of the processing of compound words is extremely rare. There have only been five such cross-linguistic studies done so far, and they compared the results from the following languages: Dutch vs. English (Schreuder et al. 1998), Greek vs. Polish 
(Kehayia et al. 1999), French vs. Bulgarian (Jarema et al. 1999), German vs. Greek vs. Polish (Baayen et al. 2002), Dutch vs. English (de Jong et al. 2002). Other single-language studies included nine languages: English (Libben 1998; Fiorentino, Fund-Reznicek 2009), German (Bronk et al. 2013), Dutch (Sandra 1990; Zwitserlood 1994), Italian (Delazer, Semenza 1998; Mondini et al. 2004; Marelli, Luzzatti 2012), Greek (Dalalakis 1999), Finnish (Mäkisalo et al., 1999), Hebrew (Berman, Clark 1989), Chinese (Zhou, Marslen-Wilson 1994) and Japanese (Kudo 1992), and one additional study concentrated on French-English bilingual speakers (Nicoladis 2002). The languages investigated in these studies represent language families that are typologically different: Slavic, Romance, Germanic, Sino-Tibetan, Semitic, Japanese-Korean and Uralic. To the best of our knowledge, Slavic languages are under-represented. All these studies point to the fact that semantic transparency is considered one of the most crucial factors affecting compound processing. Compounds vary in terms of the degree of semantic transparency. A standard division includes four degrees of semantic transparency: (i) transparent (TT) (when the sum of the meanings of the constituents activates the meaning of the entire compound), e.g. blueberry; (ii) opaque (OO) (when neither constituent activates the meaning of the entire compound), e.g., humbug ('dishonest act'); (iii) left-hand opaque (OT) (when the meaning of the rightmost constituent pointstothemeaning of thecompound, but theleftmostdoesnot), e.g.strawberry; (iv) right-hand opaque (TO) (when the meaning of the leftmost constituent points to the meaning of the compound, but the rightmost does not), e.g. shoehorn ('a curved object that you use for helping you to put your shoe on'). Sandra (1990) confronted fully opaque compounds in Dutch with fully transparent ones and found that only these transparent showed priming effects, which led Sandra to the conclusion that opaque compounds are listed and transparent compounds are decomposed. In another study, Zwitserlood (1994) found priming effects for fully transparent and partially opaque compounds but not for fully opaque ones. Libben (1998), on the other hand, found semantic priming for compounds of all four types of semantic transparency, additionally suggesting that Sandra's priming technique aimed at "lines of connections within the mental lexicon," rather than activation during lexical identification. El-Bialy et al. (2013) in their study of English compounds, obtained results which were most surprising: they found semantic priming for fully transparent and fully opaque compounds but not for partially opaque ones. Alarmingly, it does not seem to be the case that the constituent's opacity establishes whether component's semantics affects compound processing. Conversely, their results point to the conclusion that the constituent's semantics is always accessible. However, depending on the degree of both components' opacity (fully opaque or partially opaque of either type: transparent-opaque and opaque-transparent), their semantics may have different effects (El-Bialy et al. 2013, pp. 92-93). 
Thus, the data gathered in their study indicate that semantic transparency emerges as a feature of processing, not of representation. Although the outcomes of these studies are somewhat mixed (Libben 1998), the evidence from priming experiments indicates that (partially) opaque compounds are decomposed for French, Bulgarian (Kehayia et al. 1999), Greek, Polish (Jarema et al. 1999), English (Frisson et al. 2008; El-Bialy et al. 2013), Finnish (Pollatsek, Hyöna 2005) and Dutch (Zwitserlood 1994). Therefore, to further explore the impact of semantic transparency in context of the ongoing discussion in the literature, we planned a masked priming lexical decision experiment testing the processing of Polish transparent and opaque compounds. In designing our experiment we rely on the view that the mental lexicon is comprised of associative links between words. Semantic relatedness is determined via the degree of links between words in terms of lexical relations. Words which are related to one another often fall into the same lexical paradigm, e.g. parts of the body (head, hair) or types of females (madam, lady). Spreading activation model (Collins, Loftus 1975) posits that when the words have many features in common, the connection between these words is strong and they may be easily activated. Semantic priming determines the influence of one word (the prime item) on the second word (the target item). It has been proved that in semantically related prime-target pairs of words such as for instance cat-dog, the prime cat facilitates the responses to the target $\log$ as compared to the responses to semantically unrelated pairs such as for example nurse-dog in picture naming or lexical decision tasks. There are two kinds of priming experiments: normal (or standard) and masked. The masked semantic priming has been used to test the early stages of visual-word identification (Grainger 2008; Kinoshita, Lupker 2003). The standard procedure in a masked priming experiment begins with a mask (i.e. the group of hash tag symbols, e.g. \#\#\#\#), remaining on the screen for $500 \mathrm{~ms}$, which is subsequently followed by a prime word. The prime word is presented for, typically, $50 \mathrm{~ms}$, replaced by the target word. Under such conditions, subjects are unaware of the prime's status (i.e. what the prime word is), and virtually always even of its existence (statistically approximately $98 \%$ of participants; see Gomez et al. 2013). An important advantage of the masked priming paradigm is that some sorts of episodic or strategic influences may be averted. The masked priming technique has turned into a critical testing paradigm for decomposition during compound word recognition. It is argued (e.g., Fiorentino, Poeppel 2007) that masked priming generates morphological effects during compound recognition which are dissociable from the types of semantic effects and formal overlap effects that are considered to influence processing in techniques, such as semantic priming. Because the interval between prime items and target compounds is very short, it allows us to view early processes, in which we are particularly interested in the present paper. 


\section{Experiment description}

\section{Experimental material and hypotheses}

In the study reported here, we tested current models of morphological processing with data from the visual lexical decision experiment with masked semantic priming using Polish compounds and monomorphemic words. There were four conditions in the experiment presented in (1a)-(1d) below:

(1) (a) condition 1: semantically transparent compound words, e.g. bajkopisarz 'fairy-tale writer', lit. bajka 'fairy tale' + pisarz 'writer';

(b) condition 2: semantically opaque compound words, e.g. duszpasterz 'priest', lit. dusza 'soul' + pasterz 'shepherd';

(c) condition 3: heads (i.e. simple words) taken from transparent compounds, e.g. pisarz 'writer';

(d) condition 4: heads (i.e. simple words) taken from opaque compounds, e.g. pasterz 'shepherd'.

Under these conditions, we address the following questions: To what extent does morphological internal structure play a role when accessing compound words? Are semantically opaque compounds processed differently than semantically transparent ones? If decomposition occurs, does it entail some additional processing costs?

\section{Generating a set of transparent and opaque compounds in Polish}

Semantic transparency aims to seize the intuitive difference between compounds like greenhorn and flowerpot. Zwitserlood (1994) defines semantically transparent compounds as those which are based on the literal interpretations of the components. However, as pointed out in Lieber and Štekauer (2012) the transparency/opacity distinction is not an either/or question. It is rather referred to in terms of degrees of transparency. ${ }^{3}$ Moreover, as pointed out in Reid and Marslen-Wilson (2003, p. 330), a combinatorial criterion according to which the meaning of a complex form is computed by combining the meanings of its morphemic constituents cannot be used to define transparency. This is so because it is possible for subjects to rate a pair of words as being semantically transparently related without the meaning of the forms involved necessarily being fully compositional. For example, a word like wiazanka 'a bunch' is transparently related to the verb wiazać 'to tie', from which it is derived, but its meaning, nonetheless, is not the simple composition of the meaning of the

\footnotetext{
${ }^{3}$ We would like to thank here one of the anonymous reviewers for this remark.
} 
root and the meaning of the derivational morpheme. Therefore, the concept of semantic transparency cannot be treated as fully equivalent with the concept of semantic compositionality. For this reason, we decided to operationalize transparency by testing native speaker intuitions about the degree of transparency of compound words on a scale. This method is frequently used in psychological research, where such relative concepts as beauty, stress, anxiety, brightness, colour intensity undergo operationalization (Noordman Vonk, 2015). In order to select a set of transparent and opaque compound to be tested in our planned experiment, an initial set of 60 nominal compound words was taken from the literature and from the Polish Corpus, PELCRA NKJP 1.0 (http:// www.nkjp.uni.lodz.pl/index.jsp). Especially troublesome was finding opaque compounds as they are very rare in Polish. Yet based on our own intuitions and on the interview with other native speakers of Polish, it was established that at least 23 of the 60 pre-selcted compounds were potentially opaque. We conducted a rating study on 10 independent native speakers of Polish, whose task was to indicate how related the particular compound word was with its constituent elements (a similar method was used in the study conducted by Marelli et al. 2009). The participants were instructed to rate each compound on the scale from 1 to 7 , assessing the extent to which the meaning of the compound was predictable from the meanings of its components ( 1 was used for "very unpredictable" and 7 for "very predictable"). The means were calculated from the obtained results. Two lists, one of 20 transparent compounds (with the highest score, i.e. above 5,1) and the second one of 20 opaque compounds (with the lowest score, i.e. below 3,7), were selected from the rating.

We tested the priming of head constituents, using a noun semantically related to the head constituents as masked primes, compounds and simple words as targets (e.g. for compounds: szosa 'highway' - ZAWALIDROGA 'obstacle', lit. 'fall + road'; for simple words: pasja 'passion, hobby' - MANIA 'mania'). The prime-target pairs contained 40 primes paired with compound words and 40 same primes paired with simple words. The targets included 20 relatively semantically transparent Polish compounds (e.g. BAJKOPISARZ 'fairy tale writer') with their monomorphemic heads (e.g. PISARZ 'writer') and 20 relatively semantically opaque Polish compounds (e.g. LEKKODUCH 'happy-go-lucky person') with their monomorphemic heads (e.g. $D U C H$ 'ghost'). The primes consisted of 20 nouns semantically related to the head components of semantically transparent compounds (e.g. autor 'author') and 20 nouns semantically related to the head components of semantically opaque compounds (e.g. zjawa 'apparition'). To prevent the subjects from seeing the same prime word twice, we divided the experiment into two counterbalanced sets: set A and set B. See Appendix A for a full list of items and Table 1 for examples.

We additionally ensured that the prime words used in our study are dissociated from the possible overlap of form or phonology with respect to the 
compounds they primed. In the study of El-Bialy et al. (2013) and Fiorentino, Fund-Reznicek (2009) - in which they employed the semantic priming technique to test the processing of English compounds but they used non-head constituents as targets and compounds as primes, e.g. blackbird-BLACK - it was found that the prime words might not only be responsible for activating semantic information of the target words, but also some additional undesirable information that could come from an orthographic and/or phonemic overlap (see Hwaszcz 2016). Thus, we wanted to minimize the possible interfering conditions.

All experimental items were matched for full-form frequency (confirmed by ANOVA test, p-value $=.2167$ ), length, the number of word formation processes as well as congruity of prime/target phonemic and orthographic overlap (within the three conditions). The heads of compounds were also matched for surface frequency ( $\mathrm{p}$-value $=.7692$ ) as well as lemma frequency (p-val$\mathrm{ue}=.9567$ ). Additionally, the head frequency of occurrence was always higher than the compound full form frequency. The frequency of occurrence was gathered using the Polish Corpus, PELCRA NKJP 1.0. There were two nominal compound words used in the experiment which also function in the Polish language as adjectives: złotousty ('golden-mouthed person' or 'goldenmouth') and jednoręki ('one-armed person' or 'one-armed), but they were used in two different conditions and therefore they were counterbalanced (złotousty as opaque and jednoręki as transparent). ${ }^{4}$ Other compounds used in the study were counterbalanced for morphological complexity (i.e. there was an equal number of morphologically complex transparent and opaque compounds).

Additional 40 non-existing words were added as fillers to the experiment: half of them functioned as morphologically legal pseudo-compounds created by adding or altering letters of existing long and rare Polish words of foreign origin (e.g. ABIERETYNA, created out of ABIETYNA 'abietin'); the rest functioned as morphologically legal words similar in length to simple words used in the experiment (e.g. ETEKS). The primes used to these fillers were simple random words (e.g. strzał 'shot'). The fillers were used to make the ratio of word/non-word equal 1:1. In order to ensure that length and frequency would not affect the lexical decision, the differences in the length and corpus frequencies of the experiment input data were compared. As the distributions of the data were not parametric, Wilcoxon Signed Rank Test was used for compound

${ }^{4}$ The following examples, taken from the Polish corpus, illustrate that these adjective-like compounds indeed function as nouns: "Po chwili wracasz do przerwanej relacji, by przekonać się, na co jeszcze stać $z$ łotoustego" (You come back to the disrupted conversation after a moment only to find out what else the golden-mouthed is capable of doing); "Jak tańczyli Jegorowicz i Czaka wokół tego jednorękiego, zresztą nie tylko oni” (How Jegorowicz and Czaka danced around this one-armed, besides they weren't the only ones). 
Table 1. Examples of Prime and Target Items (the upper part - set A, the lower part - set B)

\begin{tabular}{|l|l|l|}
\hline \multicolumn{1}{|c|}{ Condition } & \multicolumn{1}{c|}{ Example Prime } & \multicolumn{1}{c|}{ Example Target } \\
\hline Transparent Compound & autor & BAJKOPISARZ \\
\hline Opaque Compound & buzia & ŻÓŁTODZIÓB \\
\hline $\begin{array}{l}\text { Transparent Compound } \\
\text { Head }\end{array}$ & zestaw & ZBIÓR \\
\hline Opaque Compound Head & zjawa & DUCH \\
\hline Transparent Compound & zestaw & GWIAZDOZBIÓR \\
\hline Opaque Compound & zjawa & LEKKODUCH \\
\hline $\begin{array}{l}\text { Transparent Compound } \\
\text { Head }\end{array}$ & autor & PISARZ \\
\hline Opaque Compound Head & buzia & DZIÓB \\
\hline
\end{tabular}

frequency, head frequency and prime length comparisons and Kruskal-Wallis ANOVA was applied to compound length, head length and prime-target compound-target head comparison. The lexical properties of all condition and filler words (containing the statistical tests within the conditions) are illustrated in Table 2.

\section{Predictions}

The following predictions have been formulated on the basis of the conditions in (1) and the models of morphological processing. Firstly, we compare conditions (1a) and (1b) to test whether access to the head component is easier in the case of transparent ones, which would be manifested in shorter reaction times. Secondly, we compare the overall response times to heads (1c-1d) and to compound words $(1 \mathrm{a}-1 \mathrm{~b})$ and expect simple words to elicit shorter times because of their less morphological complexity. And thirdly, we expect no differences in the processing of heads (1c) and (1d) because they are similar in both length and frequency of occurrence.

\section{Subjects}

Forty-two undergraduate students (fourteen male and twenty-eight female, aged 19-24 - age mean 20,5) from the University of Wrocław, all native speakers of Polish with normal or corrected vision agreed to take part in this experiment by providing the written consent of their own free will. None of the subjects took part in both sets. The overall number of trials for each subject was 80 . 
Table 2. Properties of stimuli

\begin{tabular}{|l|l|l|l|}
\hline \multirow{2}{*}{} & \multicolumn{2}{|c|}{ Condition } & \multirow{2}{*}{ ANOVA } \\
\cline { 2 - 3 } & \multicolumn{1}{|c|}{ Transparent } & Opaque & \\
\hline Compound Length & 9.5 & 9.7 & \multirow{2}{*}{$\chi^{2}(5)=3.19, \mathrm{p}=.671$} \\
\hline Compound Head Length & 4.8 & 4.8 & $\chi^{2}(4)=8.52, \mathrm{p}=.074$ \\
\hline Prime Length & 5.1 & 5.0 & $\mathrm{~W}=201, \mathrm{p}=.989$ \\
\hline Compound Frequency & 273 & 181 & $\mathrm{~W}=136, \mathrm{p}=.217$ \\
\hline Compound Head Frequency & 35108 & 33312 & $\mathrm{~W}=182, \mathrm{p}=.957$ \\
\hline Prime Frequency & 32398 & 31789 & $\mathrm{~W}=198, \mathrm{p}=.832$ \\
\hline Prime-Target Overlap & 3097 & 3421 & $\chi^{2}(36)=37.18, \mathrm{p}=.415$ \\
\hline
\end{tabular}

\section{Procedure}

One stimulus at a time was presented on the screen, centred horizontally, in Arial font, point size 24, with white text on a black background, with each successive stimulus replacing the previous one. The experiment was conducted by means of PsychoPy software (available at http://www.psychopy.org). There was a trial session to acquaint participants with the rules of the experiment - 10 practice trials were shown at the onset of the experiment. The order of stimuli presentation was randomized for each subject. The experiment was preceded by an array of instructions which stated that participants would see a letter string in the centre of the screen and their task would be to decide as quickly and as accurately as possible whether the string of letters was a word or a nonword in the Polish language. Every trial began with a $500 \mathrm{~ms}$ forward mask a group of hash tag symbols (i.e. \#\#\#), identical in the number of letters with the prime which followed. The mask was replaced with the prime word for 50 $\mathrm{ms}$ written in lower-case and was at once followed by the target word written in upper-case for $2500 \mathrm{~ms}$ timeout or until the response (see e.g. Bodner, Masson 2003, for discussion of methodology). The responses were made by pressing either the left arrow key or the right arrow key, depending on the set. In set A the left arrow key was assigned "word" response, while the right arrow key was assigned "non-word" response; in set B the assignments were the opposite.

\section{Results}

Six outlying values were removed in set A and set B. Reaction times and accuracy rates are illustrated in Table 3 . The analysis was ultimately carried out on 120 logarithmic transformed mean RTs obtained from 30 participants $(30$ observations per condition). The distribution of the analysed data is presented below in Fig. 1. 


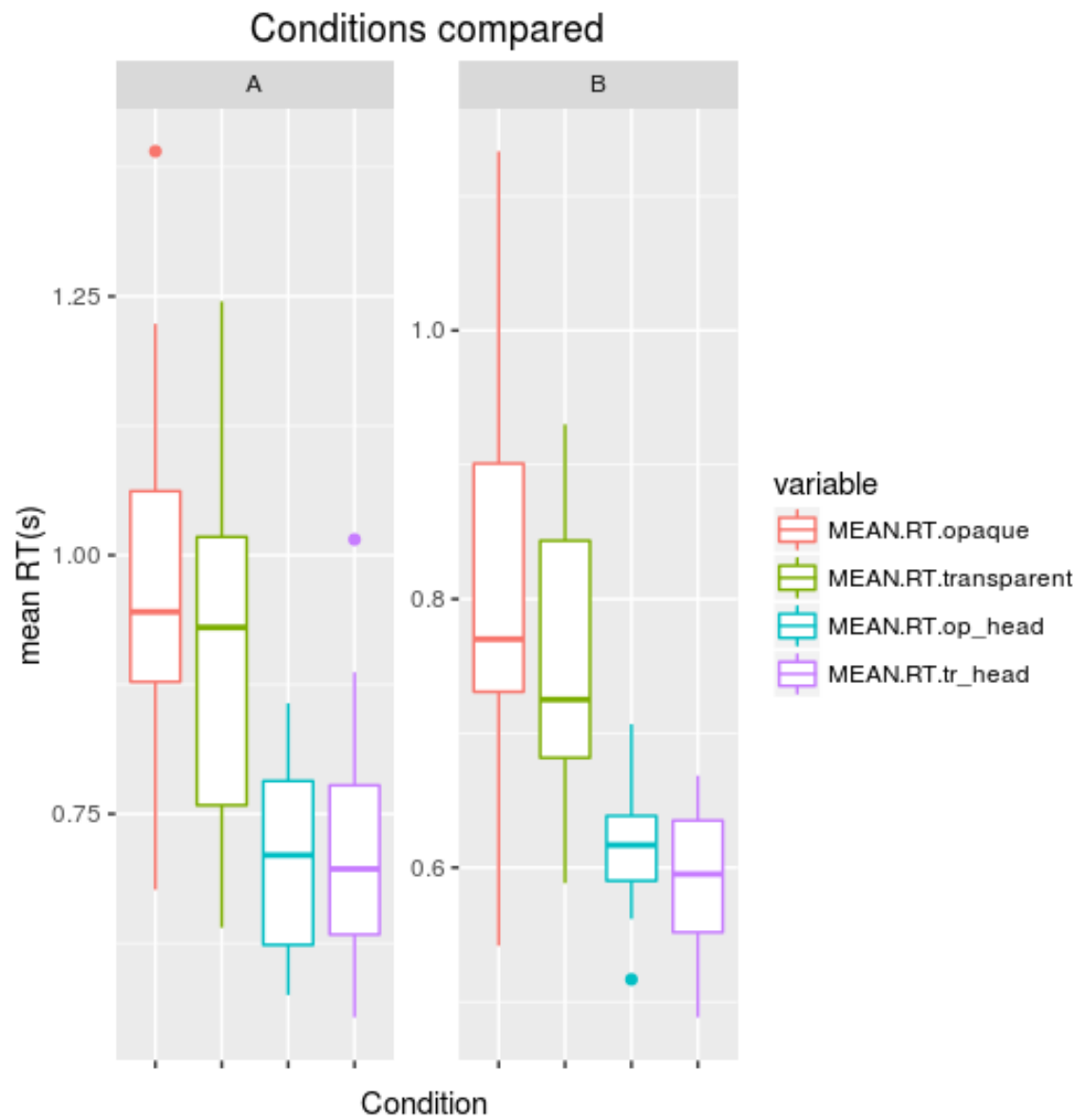

Fig. 1. Conditions compared

A mixed-model for paired measurements was built for analysing the mean $\operatorname{logRTs}$. Mean $\operatorname{logRT}$ and 95\% CIs for the tested conditions are illustrated below in Fig. 2.

Mixed model results indicated significant main effects for $\operatorname{SET}(\mathrm{F}(3,28)$ $=13.765, \mathrm{p}=.0009)$ and CONDITION. The assumptions of sphericity of variances were violated $(\mathrm{W}=0.443, \mathrm{p}=.0006)$ for the Condition main effect, therefore Greenhouse-Geisser correction was applied $(F(1.98,55.44)$ $=72.449, \mathrm{p}<.001)$. There was no significant interaction effect between SET and CONDITION $(\mathrm{F}(3,84)=0.575, \mathrm{p}=.636)$. Effect size for SET equals to $25 \%$ ( $25 \%$ of the observed difference between the data is accounted for by the differences between items in set A and set B). Effect size for CONDITION amounts to $44 \%$. (44\% of the observed difference between the data is accounted for by the differences between items in Transparent Compound, 


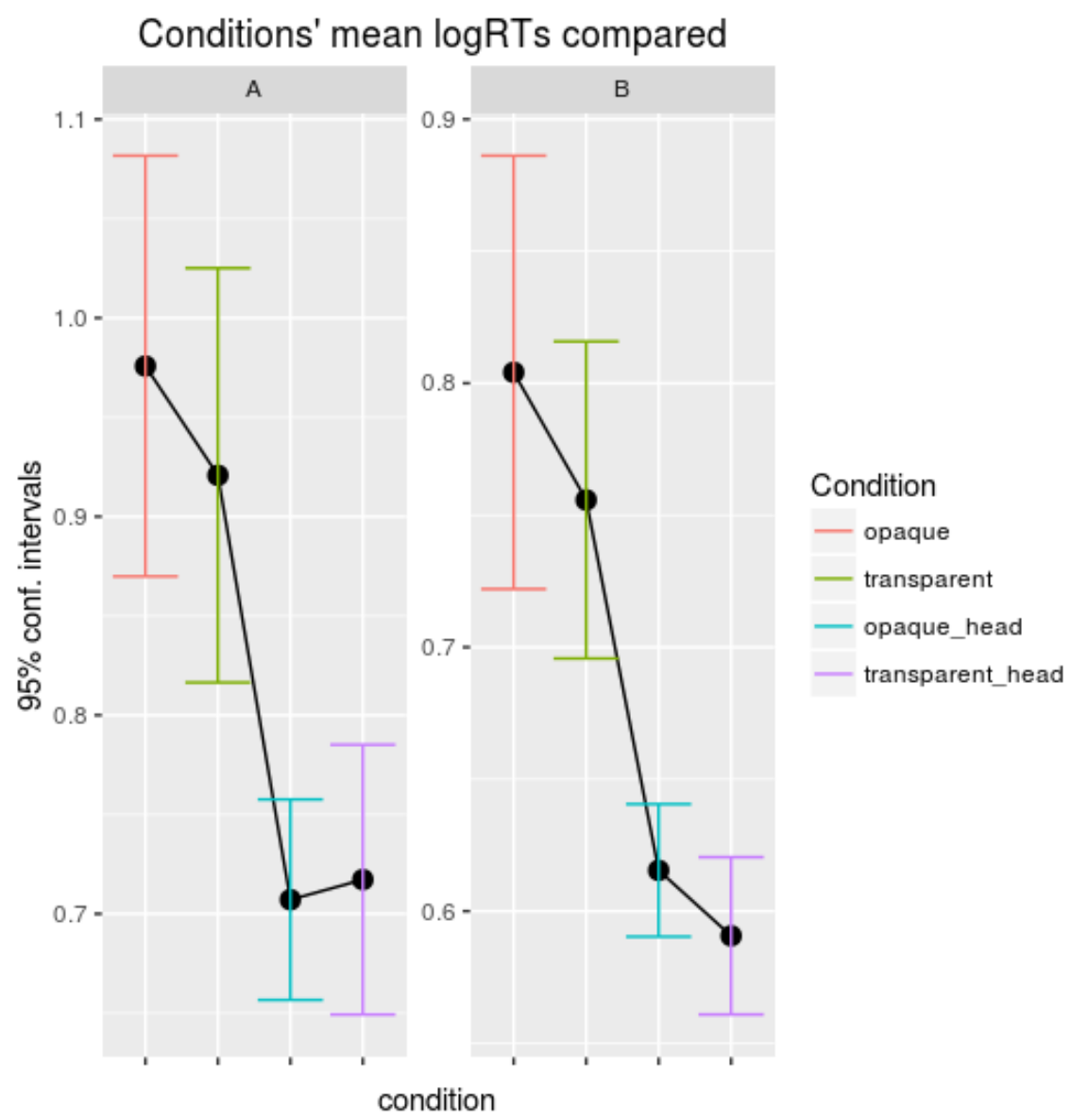

Fig. 2. Conditions' mean logRTs compared

Opaque Compound, Transparent Compound Head and Opaque Compound Head).

The significant main effect for SET variable shows that the two sets of items that the participants were tested on do not differ significantly from each other. With respect to the main effect for CONDITION pair-wise comparisons were significant for the comparison between Opaque Compound and Transparent Compound items $(\mathrm{p}=.045)$, Opaque Compound and Opaque Compound Head $(\mathrm{p}<.001)$, Opaque Compound and Transparent Compound Head $(\mathrm{p}<$ $.001)$, Transparent Compound and Transparent Compound Head $(\mathrm{p}<.001)$ and Transparent Compound and Opaque Compound Head $(\mathrm{p}<.001)$. The compression between Opaque Compound Head and Transparent Compound Head was insignificant $(\mathrm{p}=1)$. 
Table 3. Masked priming of head/word-final position

\begin{tabular}{|l|l|l|l|}
\hline \multirow{2}{*}{ Condition } & \multicolumn{2}{|c|}{ Response time in ms. (error \%) } & \multirow{2}{*}{ Mean Difference } \\
\cline { 2 - 3 } & \multicolumn{1}{|c|}{ Compound } & Compound Head & \\
\hline Transparent & $889(2,9 \%)$ & $721(1,4 \%)$ & $-168^{* *}$ \\
\hline Opaque & $952(8,6 \%)$ & $701(0,7 \%)$ & $-251^{* *}$ \\
\hline & \multicolumn{1}{|c|}{ Transparent } & Opaque & \\
\hline Compound & $889(2,9 \%)$ & $952(8,6 \%)$ & $+63^{*}$ \\
\hline Compound Head & $721(1,4 \%)$ & $701(0,7 \%)$ & -20 \\
\hline
\end{tabular}

${ }^{*} p<.05 .{ }^{* *} p<.01$.

\section{Discussion}

The reported experiment elicited significant masked priming effect for the head components of transparent compound words in Polish. The magnitude of the effect was significantly different within the two conditions: relatively transparent and relatively opaque compounds. Moreover, the difference found for masked priming effect within the heads of the two types of compounds was insignificant. The priming effects observed in this study patterned like those reported by Bronk et al. (2013) for German compound words using the standard priming technique.

Let us now refer to the predictions made in the previous section of this paper. As for the comparison between transparent and opaque compounds, transparent ones elicited significantly shorter reaction times, which indicates that we have access to the head component for transparent compounds in Polish: the target word was activated by the prime word due to semantic associations between the two words. No statistically significant differences have been found in the case of the two types of heads (taken from semantically transparent and semantically opaque compounds) as has been expected. As for the last prediction, the overall response times to heads was faster than to compound words. This points to the conclusion that compound words take more time to process (but it may not solely be the result of the differences in morphological complexity, but by some other factors, such as the number of letters or lower word frequency).

\section{General discussion}

The study aimed at expansion of our understanding of the factors that influence the selection of the route (decomposition / storage) during visual recognition of morphologically complex words. The focus of the experiment was on 
the issue whether visually presented compound words in Polish are decomposed into their component morphemes during word identification, and, if decomposition occurs, what costs it brings as a result of this decomposition. Additionally, the centre of interest involved the possible impact of semantic transparency on compound processing with respect to the mentioned issues.

The results obtained in this study demonstrate that masked priming is modulated by semantic transparency: the semantic relations between the prime word and the target word significantly affected participants' response times (although the effect size is relatively small - eta $=.25$ ). These results indicate that semantic priming was higher for transparent than for opaque compounds. The effect of semantic transparency in masked priming has been rejected by previous research using this technique (e.g. Orfanidou et al. 2010; Amenta, Crepaldi 2012). Instead, it has been established that the masked priming paradigm encourages a type of decomposition which segments all morphologically complex words into their components - this particular type of decomposition is called "morpho-orthographic decomposition" (for discussion see Rastle et al. 2004).

With respect to the issue of semantic transparency, the present results can be accounted for in two-fold manner. Primarily, most of the literature on the masked priming technique has focused on languages such as Italian, English or Dutch, and here, for the first time, the object of the study were compound words in the Polish language. The type of language, as has been mentioned, may play a crucial role in compound processing. Polish morphological system (affixation and derivation) is far richer than, for instance, the English one. On the other hand, the process of compounding in English is highly productive and constitutes a substantial part of language; however, in Polish, compounding is less productive and constitutes a relatively small portion of language. Therefore, the processes used by Polish native speakers while processing Polish compounds may be different from those used by, for instance, English native speakers while processing English compounds. Secondarily, the idea behind morpho-orthographic decomposition is that both transparent and opaque compounds are decomposed. Although the obtained data suggest that these two types of compounds in Polish are processed in two different ways, it does not have to be at the decomposition level. Both transparent and opaque compounds can be initially parsed into their constituent forms, and after decomposition they follow different routes depending on the semantic conflict(for opaque compounds - consecutive operations take more time) or its lack (for transparent compounds - consecutive operations take less time) between the meanings of the constituents and the meaning of the entire compound.

A similar explanation was reported in the studies conducted by Ji et al. (2011) and by Bronk et al. (2013), which are closely related to our own. They 
investigated English and German compounds, respectively. Ji et al. (2011) assume that early morphological decomposition must be followed by the necessary constituent integration to access the word's meaning. Bronk et al's results provide strong evidence for decomposition and support the existence of a reassembly stage (when the constituent representations are integrated into a unitary representation). The results of our experiment, which corroborate with those reported by Ji et al. and Bronk et al., demonstrate that reactions were faster to semantically transparent compounds than to semantically opaque ones, and the difference was statistically significant. There was no significant difference between the two types of monomorphemic nouns (heads of semantically opaque and transparent compounds), which indicates that they were processed equally fast, but in most cases (apart from zbiór 'collection', $w y \dot{z}$ 'high pressure', mania 'mania', dzieło 'work, composition') faster than compound words. This finding strongly speaks in favour of decomposition because otherwise there would be no statistical differences between mono- and multimorphemic words if they were all accessed via listing. None of the models which suggest that there is direct access to all words - including the complex ones - may account for our results. Therefore, the data from the study are inconsistent with the assumptions of the full-listing model, put forward by Butterworth (1983), nor with the supra-lexical model, as suggested by Giraudo and Grainger (2001).

The results obtained in the experiment are consistent with the current approaches to compound processing: CAA and MCA, because these models allow for the differences in processing resulting from semantic transparency. MCA model seems particularly interesting because it suggests that opaque components slow down compound processing as the result of the contradiction between the computed meaning and the traditional lexicalized meaning. This model might explain the obtained data even better as the results provide evidence for additional processing costs for opaque compounds, which can be accounted for by the necessary rejection of the constructed meaning to arrive at the stored representation. As far as dual-route models are concerned (Caramazza et al.'s AAM 1988 and Schreuder, Baayen's MRM 1995), they are also compatible with our data, because they claim that the processing of complex words involves decomposition.

To disconnect the dual-route models from Taft's obligatory decomposition model, the line of reasoning of Levelt et al. (1999) is employed. In their twostage approach to language production, the lemma representations are fullform units that combine component morphemes, and in turn allow for the access to functional and semantic properties (e.g. gender, syntactic category). Should complex word carry more semantic information than its components (and perhaps slightly different information), a lemma representation is necessary over and above the lemma representations for the components. Therefore, 
lemma is needed for all compound words as even a transparent compound carries more semantic and functional information than the combined meanings of its constituents, not to mention opaque compounds. A similar linguistic viewpoint is claimed by Jackendoff (2012), who suggests that all compounds can have different meanings when used in different contexts. Gleitman and Gleitman (1970) show that, for instance, lion-house can be interpreted in three different ways: a house for lions, a house suitable for lions, a house lions can live in. Moreover, only lemma representations for compounds can indicate the constituent relationship (for, suitable for, good for, made of, part of and so on; Gagné, Spalding 2009). In the case of fully transparent compounds, their component representations on the lemma level activate their concepts and because there is a semantic congruity between them and the meaning of the entire compound, the lemmas may facilitate visual word recognition. In the case of fully opaque compounds, the semantic incongruity between the lemma representations of the constituents and the meaning of the entire compound may be responsible for the lack of facilitation.

As has been proposed by Bronk et al. (2013), compounds may be stored in the mental lexicon as full forms, provided that they have a high lemma frequency, which indirectly reflects the number of potential encounters by a particular language user. As for the compounds used in our experiment, we have selected 5 with the highest lemma frequency to roughly determine whether this observation also applies here.

Table 4. Response times for compounds with the highest frequency of occurrence

\begin{tabular}{|l|l|l|}
\hline \multirow{2}{*}{\multicolumn{1}{|c|}{ Compound }} & \multicolumn{1}{|c|}{\begin{tabular}{c} 
Lemma frequency \\
\multicolumn{1}{|c|}{ mean: 227,2 }
\end{tabular}} \\
\cline { 2 - 4 } & \multicolumn{1}{|c|}{$\begin{array}{c}\text { Response time in ms. } \\
\text { (error \%) }\end{array}$} \\
\hline duszpasterz 'priest' & 1015 & $991(5 \%)$ \\
\hline cudzysłów 'quotation marks' & 794 & $823(0 \%)$ \\
\hline parowóz 'steam engine' & 658 & $841(0 \%)$ \\
\hline rękodzieło 'handicraft' & 574 & $847(0 \%)$ \\
\hline żywopłot 'hedge' & 560 & $823(0 \%)$ \\
\hline
\end{tabular}

The compound with the highest frequency (duszpasterz) was responded to relatively longer than most compounds used in the experiment. This might be because this compound is opaque, while the rest of the compounds with the highest lemma frequency are transparent. Although this is just a small portion of the data obtained in the experiment, it speaks in favour of decomposition followed by the reassembly stage for opaque compounds. 
To sum up, the results point to the conclusion that the processing of Polish compounds is dependent on semantic transparency in spite of the fact that compounding in Polish is less productive than in English or German. This is apparent from the positive response latencies for semantically transparent compounds due to higher frequency of their constituents than of the compounds themselves. The difference evident between reaction times for transparent and opaque compounds may be accounted for by the beneficial contribution of the component semantics to the activation of the meaning of the entire transparent compound as a unified whole. Significantly longer response times for opaque compounds may be explained in a two-fold manner: either some additional costs can occur after decomposition, i.e., the reassembly stage; or there is no decomposition of opaque compounds. The models that best fit with our outcomes are Taft's (2004) obligatory decomposition (at least in the case of transparent compounds) ${ }^{5}$ and Ji et al.s (2011) meaning computation approach and is at odds with the full-listing model proposed by Butterworth (1983). This study contributes to the current experimental research agenda on processing and representation of Polish compound words.

\section{References}

Amenta Simona, Crepaldi Davide (2012). Morphological processing as we know it: An analytical review of morphological effects in visual word identification. Frontiers in Psychology 3, 232.

ANDREws Sally (1986). Morphological influences on lexical access: Lexical or nonlexical effects? Journal of Memory and Language 25, 726-740.

BaAyen Herald R., Krott Andrea, Dressler Wolfgang U., Jarema Gonia, Libben Gary (2002). Interfixes as boundary markers in compounds. Paper presented at the Third International Conference on the Mental Lexicon, Banff, Alberta, Canada, October.

Berman Ruth A., Clark Eve (1989). Learning to use compounds for contrast: Data from Hebrew. First Language 9, 247-270.

Bodner Glen E., Masson Michael (2003). A retrospective view of masked priming: Toward a unified account of masked and long-term repetition priming. In Masked Priming: The State of the Art. Sachiko Kinoshita, Stephen J. LupKer (eds.), 57-94. New York: Psychology Press.

BradLey David (1980). Lexical representation of derivational relation. In Juncture. Mark Aronoff, Mary L. Kean (eds.), 37-55. Cambridge, MA: MIT Press.

Bronk Maria, Zwitserlood Pienie, Bölte Jens (2013). Manipulations of word frequency reveal differences in the processing of morphologically complex and simple words in German. Frontiers in Psychology 4, 546.

\footnotetext{
${ }^{5}$ Further experiment are planned to put a more definite stand on this issue.
} 
Butterworth Brian (1983). Lexical representation. In Language Production, II: Development, Writing, and Other Language Processes. Brian Butterworth (ed.), 257-294. London: Academic.

Caramazza Alfonso, Laudanna Alessandro, Romani Cristina (1988). Lexical access and inflectional morphology. Cognition 28, 297-332.

Collins Allan M., LofTus Elizabeth F. (1975). A spreading activation theory of semantic priming. Psychological Review 82, 407-428.

Dalalakis Jenny E. (1999). Morphological representation in specific language impairment: Evidence from Greek. Folia Phoniatrica et Logopaedica 51, 20-35.

De Jong Nivja H., Feldman Laurie B., Schreuder Robert, Pastizzo Matthew, BAAYEN Herald R. (2002). The processing and representation of Dutch and English compounds: Peripheral morphological and central orthographic effects. Brain and Language 81, 555-567.

Delazer Margarete, Semenza Carlo (1998). The processing of compound words. Brain and Language 61, 54-62.

Devlin Joseph T., Jamison Helen L., Matthews Paul M., Gonnerman Laura (2004). Morphology and the internal structure of words. Proceedings of the National Academy of Sciences 101, 14984-88.

El-Bialy Rowan, Gagné Christina L., Spalding Thomas L. (2013). Processing of English compounds is sensitive to the constituents' semantic transparency. The Mental Lexicon 8(1), 75-95.

Embick David, Noyer Rolf (2007). Distributed Morphology and the Syntax-Morphology Interface. In The Oxford Handbook of Linguistic Interfaces. G. RAMCHAND and C. Reis (eds.), 289-324. Oxford: Oxford University Press.

Fiorentino Robert, Fund-REZniCEK Ella (2009). Masked morphological priming of compound constituents. The Mental Lexicon 4(2), 159-193.

Fiorentino Robert, Poeppel David (2007). Compound words and structure in the lexicon. Language Cognitive Processses 22, 953-1000.

Frisson Steven, Niswander-Klement Elizabeth, Pollatsek Alexander (2008). The role of semantic transparency in the processing of English compound words. British Journal of Psychology 99, 87-107.

Gagné Christina L., SPALDING Thomas L. (2009). Constituent integration during the processing of compound words: does it involve the use of relational structures? Journal of Memory and Language. 60, 20-35.

Giraudo Hélène, Grainger Jonathan (2001). Priming complex words: Evidence for supralexical representation of morphology. Psychonomic Buletin Review 8, 127131.

Gleitman Lila R., Gleitman Henry (1970). Phrase and Paraphrase: Some Innovative Uses of Language. New York: Norton.

Gomez Pablo, Perea Manolo, Ratcliff Roger (2013). A diffusion model account of masked vs. unmasked priming: Are they qualitatively different? Journal of Experimental Psychology: Human Perception and Performance 39, 1731-1740.

GRAINGER Jonathan (2008). Cracking the orthographic code: An introduction. Language and Cognitive Processes 23, 1-35.

Hwaszcz Krzysztof (2016). The Production and Perception of Stress Patterns in Ambiguous Compound Nouns in English. Wrocław: Quaestio. 
JACKENDOFF Ray (2012). Compounding in the parallel architecture and conceptual semantics. In The Oxford Handbook of Compounding. Rochelle Lieber, Pavol ŠTeKAuer (eds.), 106-128. Oxford: Oxford University Press.

Jarema Gonia, Busson Céline, Nikolova Rossitza, Tsapkini Kyrana, Libben Gary (1999). Processing compounds: A cross-linguistic study. Brain and Language 68, 362-369.

Ji Hongbo, Gagné Christina L., Spalding Thomas L. (2011). Benefits and costs of lexical decomposition and semantic integration during the processing of transparent and opaque English compounds. Journal of Memory and Language 65, 406-430.

Juhasz Barbara J., Berkowitz Rachel N. (2011). Effects of morphological families on English compound word recognition: A multitask investigation. Language Cognitive Processes 26, 653-682.

Kehayia Eva, Jarema Gonia, Tsapkini Kyrana, Perlak Danuta, Ralli Angela, KadZielawa Danuta (1999). The role of morphological structure in the processing of compounds: The interface between linguistics and psycholinguistics. Brain and Language 68, 370-377.

Kinoshita Sachiko, Lupker Stephen (2003). Masked Priming: The State of the Art. New York, NY: Psychology Press.

Kudo Takayuki (1992). Word formation in aphasia: Evidence from Japanese Kanji words. Journal of Neurolinguistics 7, 197-216.

Kuperman Victor, Bertram Raymond, BaAyen Herland R. (2010). Processing tradeoffs in the reading of Dutch derived words. Journal Memory and Language 62, 83-97.

Lehtonen Minna, Cunillera Toni, Rodríguez-Fornells Antoni, Hultén Annika, TuOMaInen Jyrki, LaINe Matti (2007). Recognition of morphologically complex words in Finnish: Evidence from event-related potentials. Brain Response 1148, 123-137.

Leinonen Alina, Grönholm-Nyman Petra, Järvenpä̈̈ Miika, Söderholm Carina, Lappi Otto, Laine Matti, Krause Christina M. (2009). Neurocognitive processing of auditorily and visually presented inflected words and pseudowords: Evidence from a morphologically rich language. Brain Reponse 1275, 54-66.

Levelt Willem J. M., Roelofs Ardi, Meyer Antje S. (1999). A theory of lexical access in speech production. Behavioral and Brain Sciences 22, 1-38.

LibBEN Gary (1998). Semantic transparency and processing of compounds: Consequences for representation, processing and impairment. Brain and Language 61, $30-44$.

LibBEN Gary (2006). Why study compound processing? An overview of the issues. In The Representation and Processing of Compound Words. Gary LibBen, Gonia Jarema (eds.), 1-22. Oxford: Oxford University Press.

Libben Gary, Jarema Gonia (2002). Mental lexicon research in the New Millennium. Brain and Language 81, 2-11.

Lieber Rochelle, S̆TEKAUER Pavol (2012). Introduction: Status and definition of compounding. In The Oxford Handbook of Compounding. Rochelle Lieber, Pavol ŠTeKauer (eds.), 3-18. Oxford: Oxford University Press.

Longtin Catherine-Marie, Meunier Fanny (2005). Morphological decomposition in early visual word processing. Journal Memory and Language 53, 26-41. 
Lück Monika, Hahne Anja, Clahsen Harald (2006). Brain potentials to morphologically complex words during listening. Brain Research 1077, 144-52.

MANElis Leon, Tharp David (1977). The processing of affixed words. Memory and Cognition 5, 690-695.

Marelli Marco, Crepaldi Davide, Luzzatti Claudio (2009). Head position and the mental representation of nominal compounds. The Mental Lexicon 4(3), 430-454.

Marelli Marco, Luzzatti Claudio (2012). Frequency effects in the processing of Italian nominal compounds: Modulation of headedness and semantic transparency. Journal of Memory and Language 66(4), 644-664.

Marslen-Wilson William D., Hare Mary, Older Lianne (1993) Inflectional morphology and phonological regularity in the English mental lexicon. Proceedings of the $15^{\text {th }}$ Annual Conference of the Cognitive Science Society; Hillsdale, NJ: Erlbaum; 693-698.

Marslen-Wilson William D., Tyler Lorraine K. (1997). Dissociating types of mental computation. Nature 387, 592-4.

MARsLEN-Wilson William D. (2007). Morphological processes in language comprehension. In The Oxford Handbook of Psycholinguistics. M. Gareth Gaskell (ed.), 175-192. Oxford: Oxford University Press.

Marslen-Wilson William D., Tyler Lorraine K. (1998). Rules, representations and the English past tense. Trends in Cognitive Science 2, 428-35.

Mäkisalo Jukka, Niemi Jussi, Laine Matti (1999). Finnish compound structure: Experiments with a morphologically impaired patient. Brain and Language 68, 249-53.

Mondini Sara, Luzzatti Claudio, Zonca Giusy, Pistarini Caterina, Semenza Carlo (2004). The mental representation of verb-noun compounds in Italian: Evidence from a multiple single-case study in aphasia. Brain and Language 90, 470-477.

Münte Thomas F., Say Tessa, Clahsen Herald, Schiltz Kolja, Kutas Marta (1999). Decomposition of morphologically complex words in English: Evidence from event-related brain potentials. Cognitive Brain Research 7, 241-53.

Newman Aaron J., Ullman Michael T., Pancheva Roumyana, Waligura Diane L., Neville Helen J. (2007). ERP study of regular and irregular English past tense inflection. NeuroImage 34, 435-445.

Nicoladis Elena. (2002). What's the difference between "toilet paper" and "paper toilet"? French-English bilingual children's crosslinguistic transfer in compound nouns, Journal of Child Language 29, 843-63.

Noordman Leo G. M., Vonk Wietske (2015). Inferences in Discourse, Psychology of. In International Encyclopedia of the Social Behavioral Sciences. J.D. WRIGHT (ed.), ( $2^{\text {nd }}$ ed.), vol. 12, 37-44. Amsterdam: Elsevier.

Orfanidou Eleni, Davis Matt H., Ford Mike, Marslen-Wilson William D. (2010). Perceptual and response components in repetition priming of spoken words and pseudo words. Quarterly Journal of Experimental Psychology 64(1), 96-121.

Pęzik Piotr (2012). Wyszukiwarka PELCRA dla danych NKJP. In Narodowy Korpus Języka Polskiego, 253-27). Warszawa: Wydawnictwo Naukowe PWN.

Pollatsek Alexander, Hyönä Jukka (2005). The role of semantic transparency in the processing of Finnish compound words. Language Cognitive Processes 20, 261-290. 
Rastle Kathleen, Davis Matt H., New Boris (2004). The broth in my brother's brothel: Morpho-orthographic segmentation in visual word recognition. Psychonomic Buletin Review 11, 1090-1098.

Reid Agnieszka A., Marslen-Wilson William D. (2003). Lexical representation of morphologically complex words: Evidence from Polish. In Morphological Structure in Language Processing. Herald R. BAAYen, Robert Schreuder (eds.), 287-336. Walter de Gruyter.

SANDRA Dominiek (1990). On the representation and processing of compound words: Automatic access to constituent morphemes does not occur. The Quarterly Journal of Experimental Psychology 42, 529-67.

SCHREUder Robert, BAAYen Herald R. (1995). Modeling morphological processing. In Morphological Aspects of Language Processing. Laurie Feldman (ed.), 131-154. Hillsdale, NJ: Lawrence Erlbaum.

Schreuder Robert, Neijt Anneke, Van Der Weide Femke, BaAyen Herald R. (1998). Regular plurals in Dutch compounds: Linking graphemes and morphemes? Language and Cognitive Processes 13(5), 551-573.

SzyMANEK Bogdan (2014). Osobliwości strukturalne złożeń (compositów) w języku angielskim na tle procesu kompozycji w polszczyźnie [Structural properties and idiosyncracies of compound words in English in comparison to compounding in Polish]. In Universitati serviens. Księga pamiątkowa ku czci Księdza Profesora Stanisława Wilka SDB. Ks. Jan WALKUSz i Marzena KRUPA (eds.), 605-612. Lublin: Wydawnictwo KUL.

TAFT Marcus (2004). Morphological decomposition and the reverse base frequency effect. The Quarterly Journal of Experimental Psychology 57A, 745-765.

TAFT Marcus, Forster Kenneth I. (1975). Lexical storage and retrieval of prefixed words. Journal of Verbal Learning and Verbal Behavior 14, 638-647.

Tyler Lorraine K., Marslen-Wilson William D., Stamatakis Emmanuel A. (2005). Dissociating neuro-cognitive component processes: Voxel based correlational methodology. Neuropsychologia 43, 771-778.

VANNEST Jennifer, BolAnd Julie E. (1999). Lexical morphology and lexical access. Brain and Language 68 (1-2), 324-332.

Zhou Xiaolin, Marslen-Wilson William D. (1994). Words, morphemes, and syllables in the Chinese mental lexicon. Language and Cognitive Processes 9, 393-422.

Zwitserlood Pienie (1994). The role of semantic transparency in the processing and representation of Dutch compounds. Language and Cognitive Processes 9, 341-68.

Krzysztof Hwaszcz

Dorota Klimek-Jankowska

Instytut Filologii Angielskiej

ul. Kuźnicza 22, 50-138 Wrocław

[krzysztof.hwaszcz@gmail.com]

[dorota.klimek-jankowska@uwr.edu.pl] 


\section{Appendix A}

\section{Stimuli for experiment in Set A}

Table A1. Relatively Transparent Compounds and their Primes in Set A

\begin{tabular}{|l|l|}
\hline \multicolumn{1}{|c|}{ Prime } & \multicolumn{1}{c|}{ Target (Transparent Compound) } \\
\hline autor 'author' & BAJKOPISARZ 'fairy tale writer' \\
\hline powieść 'novel' & RĘKODZIEŁO 'handicraft' \\
\hline gama '(musical) scale' & ĆWIERĆNUTA 'quarter note' \\
\hline dziura 'hole' & OCZODÓ£ 'eye socket' \\
\hline ręka 'hand' & STONOGA 'centipede' \\
\hline pojazd 'vehicle' & PAROWÓZ 'steam engine' \\
\hline wyraz 'word' & CUDZYSŁÓW 'quotation marks' \\
\hline lider 'leader' & OGNIOMISTRZ 'ordnance technician' \\
\hline nazwa 'name' & PUSTOSŁOWIE 'bunkum' \\
\hline zwłoki 'corpse' & KOŚCIOTRUP 'skeleton' \\
\hline
\end{tabular}

Table A2. Transparent Compound Heads and their Primes in Set A

\begin{tabular}{|l|l|}
\hline \multicolumn{1}{|c|}{ Prime } & \multicolumn{1}{|c|}{ Target (Transparent Compound Head) } \\
\hline lampa 'lamp' & ZBIÓR 'set' \\
\hline kreska 'line' & KROPKA 'dot' \\
\hline bestia 'beast' & ZWIERZE 'animal' \\
\hline góra 'mountain' & WYŻ 'high pressure' \\
\hline kant 'edge' & RÓG 'corner' \\
\hline sprint 'sprint' & BIEG 'run' \\
\hline mur 'wall' & PŁOT 'fence' \\
\hline ramię 'shoulder' & RĘKA 'hand' \\
\hline mózg 'brain' & GŁOWA 'head' \\
\hline sufit 'ceiling' & ŚCIANA 'wall' \\
\hline
\end{tabular}


Table A3. Relatively Opaque Compounds and their Primes in Set A

\begin{tabular}{|l|l|}
\hline \multicolumn{1}{|c|}{ Prime } & \multicolumn{1}{|c|}{ Target (Opaque Compound) } \\
\hline powiew 'puff' & PĘDZIWIATR 'roadrunner' \\
\hline $\begin{array}{l}\text { baca 'senior shepherd in the Tatra moun- } \\
\text { tains' }\end{array}$ & DUSZPASTERZ 'priest' \\
\hline zima 'winter' & PRZEBIŚNIEG 'snowdrop' \\
\hline wargi 'lips' & ZŁOTOUSTY 'golden-mouthed person' \\
\hline szosa 'highway' & ZAWALIDROGA 'obstacle' \\
\hline pieniądz 'coin/money' & DUSIGROSZ 'penny pincher' \\
\hline buzia 'mouth' & ŻÓŁTODZIÓB 'greenhorn' \\
\hline pani 'madam' & BAWIDAMEK 'ladies' man' \\
\hline brzeg 'brim/hem' & OBIBOK 'lazybones' \\
\hline system 'system' & DROBNOUSTRÓJ 'micro-organism' \\
\hline
\end{tabular}

Table A4. Opaque Compound Heads and their Primes in Set A

\begin{tabular}{|l|l|}
\hline \multicolumn{1}{|c|}{ Prime } & \multicolumn{1}{c|}{ Target (Opaque Compound Head) } \\
\hline ziemia 'earth' & SWIAT 'world' \\
\hline czoło 'forehead' & GŁOWA 'head' \\
\hline patyk 'stick' & KIJ 'cane' \\
\hline ręka 'hand' & NOGA 'leg' \\
\hline gęba 'mouth' & MORDA 'mug (mouth)' \\
\hline zjawa 'apparition' & DUCH 'ghost' \\
\hline włosy 'hair' & GŁOWA 'head' \\
\hline ptak 'bird' & PIÓRO 'feather' \\
\hline słońce 'sun' & ZIEMIA 'earth' \\
\hline pasja 'passion' & MANIA 'mania' \\
\hline
\end{tabular}




\section{Stimuli for experiment in Set B}

Table A5. Relatively Transparent Compounds and their Primes in Set B

\begin{tabular}{|l|l|}
\hline \multicolumn{1}{|c|}{ Prime } & \multicolumn{1}{c|}{ Target (Transparent Compound) } \\
\hline zestaw 'set' & GWIAZDOZBIÓR 'constellation' \\
\hline kreska 'line' & DWUKROPEK 'colon' \\
\hline bestia 'beast' & JEŻOZWIERZ 'porcupine' \\
\hline góra 'mountain' & PŁASKOWYŻ 'plateau' \\
\hline kant 'edge' & NOSOROŻEC 'rhinoceros' \\
\hline sprint 'sprint' & MARSZOBIEG 'endurance march' \\
\hline mur 'wall' & ŻYWOPŁOT 'hedge' \\
\hline ramię 'shoulder' & JEDNORĘKI 'one-armed person' \\
\hline czoło 'forehead' & PÓŁGŁÓWEK 'halfwit' \\
\hline sufit 'ceiling' & MEBLOŚCIANKA 'wall unit' \\
\hline
\end{tabular}

Table A6. Transparent Compound Heads and their Primes in Set B

\begin{tabular}{|l|l|}
\hline \multicolumn{1}{|c|}{ Prime } & \multicolumn{1}{|c|}{ Target (Transparent Compound Head) } \\
\hline autor 'author' & PISARZ 'writer' \\
\hline powieść 'novel' & DZIEŁO 'work' \\
\hline gama '(musical) scale' & NUTA 'note/tone' \\
\hline dziura 'hole' & DÓ£ 'pit' \\
\hline ręka 'hand' & NOGA 'leg' \\
\hline pojazd 'vehicle' & WÓZ 'cart' \\
\hline wyraz 'word' & SŁOWO 'word' \\
\hline lider 'leader' & MISTRZ 'master' \\
\hline nazwa 'name' & KSIĄŻKA 'book' \\
\hline zwłoki 'corpse' & TRUP 'dead body' \\
\hline
\end{tabular}


Table A7. Relatively Opaque Compounds and their Primes in Set B

\begin{tabular}{|l|l|}
\hline \multicolumn{1}{|c|}{ Prime } & \multicolumn{1}{c|}{ Target (Opaque Compound) } \\
\hline ziemia 'earth' & OBIEŻYŚWIAT 'globetrotter' \\
\hline czoło 'forehead' & WODOGŁOWIE 'hydrocephaly' \\
\hline patyk 'stick' & WŁÓCZYKIJ 'rolling stone' \\
\hline ręka 'hand' & HULAJNOGA 'scooter' \\
\hline gęba 'mouth' & MOCZYMORDA 'soak' \\
\hline zjawa 'apparition' & LEKKODUCH 'happy-go-lucky person' \\
\hline włosy 'hair' & ŁAMIGŁÓWKA 'puzzle' \\
\hline ptak 'bird' & GRYZIPIÓREK 'petty official' \\
\hline słońce 'sun' & CZARNOZIEM 'charnozem' \\
\hline pasja 'passion' & GRAFOMAN 'scribbler' \\
\hline
\end{tabular}

Table A8. Opaque Compound Heads and their Primes in Set B

\begin{tabular}{|l|l|}
\hline \multicolumn{1}{|c|}{ Prime } & \multicolumn{1}{c|}{ Target (Opaque Compound Head) } \\
\hline powiew 'puff' & WIATR 'wind' \\
\hline $\begin{array}{l}\text { baca 'senior shepherd in the Tatra moun- } \\
\text { tains' }\end{array}$ & PASTERZ 'shepherd' \\
\hline zima 'winter' & SNIEG 'snow' \\
\hline wargi 'lips' & USTA 'mouth' \\
\hline szosa 'highway' & DROGA 'road' \\
\hline pieniądz 'coin/money' & GROSZ 'grosz (Polish currency)' \\
\hline buzia 'mouth' & DZIÓB 'beak' \\
\hline pani 'madam' & DAMA 'lady' \\
\hline brzeg 'brim/hem' & BOK 'side' \\
\hline system 'system' & USTRÓJ 'system/regime' \\
\hline
\end{tabular}

